Sains Malaysiana 49(11)(2020): 2785-2791

http://dx.doi.org/10.17576/jsm-2020-4911-17

\title{
Eye Blinking Patterns, Corneal Staining and Compliance in a Group of Soft Contact Lens Wearers
}

(Corak Kerdipan Mata, Pewarnaan Kornea dan Komplians pada Satu Kumpulan Pemakai Kanta Sentuh)

\author{
Bashirah IShaK*, Nur Sakinah SaAd, Lim Siew Lee, Norlaila Mat Daud, Bariah Mohd Ali \& Norhani \\ MOHIDIN
}

\begin{abstract}
Many factors influence the success of contact lens wear, including lens surface moisture, which is affected by blinking. This study was conducted to determine the eye blinking patterns, corneal staining, and compliance in a group of soft contact lens (CL) wearers. Forty-one soft CL wearers and 41 age-matched control subjects (non-CL wearers) were recruited in this study. Blinking patterns were assessed with a digital camera attached to a slit lamp biomicroscope. Corneal staining was graded using Institute for Eye Research (IER) grading scale with 0.1 increments. The subject's compliance level was determined using a questionnaire. There was no difference in eye blinking patterns between the $C L$ wearers and control group (Mann-Whitney, $p=0.231$ ). The average grades of corneal staining in $C L$ wearers and control group were $0.38 \pm 0.39$ and $0.01 \pm 0.08$ unit, respectively. There was a significant difference in corneal staining between the two groups (Mann-Whitney, $p=0.021$ ). A significant positive correlation was found between blinking patterns and corneal staining (Spearman $\rho=0.378, p=0.015$ ). Our results also showed that $63.4 \%$ of the $C L$ wearers had good compliance towards lens care. In our multiple linear regression analysis, blinking patterns contributed significantly to corneal staining $(B=0.140, p=0.015)$, while compliance level did not $(B=-0.038, p=$ 0.471). Overall, eye blinking patterns in CL wearers influenced the risk of corneal staining.
\end{abstract}

Keywords: Blinking pattern; compliance; corneal staining; soft contact lens

\section{ABSTRAK}

Terdapat banyak faktor mempengaruhi kejayaan pemakaian kanta sentuh, termasuklah kelembapan permukaan kanta yang dipengaruhi oleh kerdipan mata. Kajian ini dijalankan untuk menentukan corak kerdipan mata, pewarnaan kornea dan komplians pada satu kumpulan pemakai kanta sentuh (KS). Empat puluh satu pemakai KS lembut dan 41 subjek kawalan (bukan pemakai KS) dengan umur yang sama direkrut untuk kajian ini. Corak kerdipan dinilai dengan kamera digital yang dilekatkan pada lampu celah biomikroskop. Pewarnaan kornea digred menggunakan skala penggredan Institute for Eye Research (IER) dengan kenaikan 0.1. Tahap komplians subjek ditentukan dengan menggunakan soal selidik. Didapati tiada perbezaan pada corak kerdipan mata antara pemakai KS dan kumpulan kawalan (MannWhitney, $p=0.231$ ). Gred purata pewarnaan kornea pemakai KS dan kumpulan kawalan adalah $0.38 \pm 0.39$ dan 0.01 \pm 0.08 unit. Terdapat perbezaan signifikan pada pewarnaan kornea antara kedua-dua kumpulan (Mann-Whitney, $p=$ 0.021). Terdapat korelasi positif signifikan antara corak kerdipan dan pewarnaan kornea (Spearman $\rho=0.378, p=$ 0.015). Keputusan kajian juga menunjukkan 63.4\% pemakai KS mempunyai komplians yang baik terhadap penjagaan kanta. Melalui analisis regresi linear berganda, didapati corak kerdipan mata menyumbang secara signifikan kepada pewarnaan kornea $(B=0.140, p=0.015)$ manakala tahap komplians tidak $(B=-0.038, p=0.471)$. Keseluruhannya, corak kerdipan mata pemakai KS mempengaruhi risiko terhadap pewarnaan kornea.

Kata kunci: Corak kerdipan; kanta sentuh lembut; komplians; pewarnaan kornea

\section{INTRODUCTION}

Eye blinking is a fast movement of eyelid closure in a short duration and can be divided into four patterns: Complete (full blinking), incomplete, twitch and force (Collins et al. 1989; Kikkawa et al. 2003). Types of blinking can be divided into reflex and spontaneous eye blinking (Hart 1992). Spontaneous eye blinking maintains the integrity of the cornea through the tear exchange system, removes impurities beneath the surface of contact lenses (CL), and maintains hygiene and lens surface moisture (Carney \& Hill 
1984). Eye blinking occurs without any external stimulus and at a constant rate and characteristics such as speed and blink duration can vary significantly, depending on the health of the eyes (Kwon et al. 2013).

Epithelial integrity can be measured through corneal staining assessment, which is widely used in clinical and research settings. Sodium fluorescein is commonly used for corneal staining. Other than staining damaged cells, sodium fluorescein can also stain healthy cells, as it reflects normal epithelial physiology (Tabery 1997). It has been reported that the corneal cells of $79 \%$ of the normal population are positively stained with fluorescein (Dundas et al. 2001). Corneal epithelium will continuously regenerate through normal cell division and undergo programmed cell death through apoptosis. Both the proliferation and cell death are important to maintain the corneal epithelium health (Bergmanson 2006).

It is more common to find corneal staining in CL wearers compared to non-CL wearers. The prevalence of corneal staining in CL wearers has been reported by Guillon et al. (1990) to be as high as $60 \%$, and approximately $54 \%$ by Nichols and Sinnott (2011). However, the staining is mostly low level and generally insignificant. In a study involving 66218 patients, the prevalence of clinically significant staining was $0.9 \%$ among soft CL wearers, $0.5 \%$ among rigid gas permeable (RGP) wearers and $1.3 \%$ among polymethylmethacrylate (PMMA) lens wearers (Hamano et al. 1985).

Patient compliance is important in all areas of medicine, and is one of the main challenges faced by health care practitioners. The risk of corneal infection is almost 80 times higher in CL wearers compared to nonCL wearers (Teenan \& Beck 2001), as $80 \%$ of CL wearers do not take care of their lenses in the prescribed manner. The low compliance level is particularly prevalent among those in the young age group and long-term CL wearers (Weisbarth \& Henderson 2005).

The main purpose of this study was to determine blinking patterns, corneal staining, and compliance level in a group of soft CL wearers. The influence of subjects' blinking patterns on corneal staining, and the association between blinking patterns, corneal staining and compliance level among soft CL wearers were also investigated.

\section{MATERIALS AND METHODS}

A total of 82 subjects participated in this cross-sectional study, comprising of 41 soft CL wearers and 41 agematched control subjects (non-CL wearers). Sample size estimation was calculated using GPower version 3.1.0, taking into consideration an additional $10 \%$ potential dropout rate. Subjects were recruited from the student population at the Universiti Kebangsaan Malaysia (UKM),
Kuala Lumpur Campus by advertisement, and word of mouth. The inclusion criteria of this study included ages between 20 and 25 years old, soft monthly or daily disposable CL wearers (Hydrogel/Silicone Hydrogel material) for at least 6 months with good general and ocular health, visual acuity of $6 / 6$ after correction with spherical correction between -1.00 and -6.00 DS and astigmatism of less than -1.00 DC for soft CL group. The exclusion criteria were subjects who did not meet the above criteria.

The study was conducted at the Optometry Primary Eye Care Clinic, Universiti Kebangsaan Malaysia, Kuala Lumpur. Informed consent was obtained from all subjects and the conduct of the study was approved by the Research Ethics Committee, Universiti Kebangsaan Malaysia, Kuala Lumpur (UKM 1.5.3.5/244/NN-0012013), according to the Declaration of Helsinki.

\section{BLINKING PATTERNS OBSERVATION}

Subjects were seated in front of a slit lamp biomicroscope, and were asked to fixate on a target placed two meters away. They were assessed with their habitual glasses in the control group and contact lenses in the CL wearers group. The right eyes' blinking patterns were recorded for one minute using a digital camera (Nikon Coolpix 4500) attached to a slit lamp biomicroscope (Topcon SL $3 F)$. A slow-motion recording of the subjects' blinking patterns was replayed and classified according to a previous study (Abelson \& Holly 1977). Complete and incomplete blinking patterns were classified from the average number of blinking in one minute for each subject. If the average number of complete blinks exceeded the incomplete blinks, subject was classified as having a complete blinking pattern, whereas subject was classified as having an incomplete blinking pattern when the average number of incomplete blinks exceeded complete blinks (Ishak et al. 2011).

\section{CORNEAL STAINING ASSESSMENT}

Corneal staining assessment was carried out after recording the blinking patterns. Prior to the start of the study, the examiner (LSL) underwent an intensive training by a contact lens consultant (BI) to minimize bias during the assessment. Corneal staining on subjects' right eyes was graded immediately after CL removal. Sodium fluorescein strips (Fluo 900, Entod Research Cell UK Ltd, London) wet with saline were applied to the superior bulbar conjunctiva. Subjects were asked to blink a few times prior to the assessment. Corneal staining was assessed under cobalt blue illumination and Wratten \#12 yellow filter over the slit lamp objective lens. The images of the cornea were captured using a digital camera (Nikon Coolpix 4500) attached to a slit lamp biomicroscope 
(Topcon SL 3F). For grading purposes, the cornea areas were divided into five zones (Figure 1): Z1-central, Z2-superior, Z3-nasal, Z4-inferior and Z5-temporal as suggested by Woods et al. (2018). Staining in each zone was graded using Institute for Eye Research (IER) grading scale with 0.1 unit of increments. The cornea staining scores were calculated based on a scoring method used in a previous study (Begley et al. 1996; Ishak et al. 2011).

\section{COMPLIANCE}

An adapted questionnaire on compliance was used to determine the subjects' compliance level on maintenance of CL, which included information on CL wearers' demographics, CL hygiene behaviours, and their attitude toward lens care (Bui et al. 2010).

\section{RESULTS}

Statistical analysis was conducted using IBM SPSS Statistics 23.0 software. The distribution of subjects by gender and race is shown in Table 1 . The mean age of the subjects was $22.37 \pm 1.34$ years for CL wearers and $21.98 \pm 1.17$ years for the control group. There was no significant difference in the mean age between the two groups (Unpaired t-test, $\mathrm{p}=0.164$ ).

\section{BLINKING PATTERNS}

In soft CL wearers, 29 (70.7\%) subjects had complete eye blinking patterns, while $12(29.3 \%)$ subjects had incomplete blinking patterns. In the control group, 30 (73.2\%) subjects had complete eye blinking patterns, and $11(26.8 \%)$ had incomplete blinking patterns. There was no significant difference in the distribution of eye blinking patterns between the two groups (Mann-Whitney, $\mathrm{p}=0.231)$.

\section{CORNEAL STAINING}

The mean grades of corneal staining of each zone in CL wearers and control group are shown in Table 2. There was a significant difference in mean grades between the five zones of the cornea in CL wearers (Friedman, $\mathrm{p}=$ 0.024). However, no significant difference in grades was found between the corneal zones for the control group (Friedman, $p=0.434$ ). The mean grades of average corneal staining in soft CL wearers and control group were 0.38 \pm 0.39 unit and $0.01 \pm 0.08$ unit, respectively. There was a significant difference in the mean grades of average corneal staining between the two groups (Mann-Whitney, $\mathrm{p}=0.021)$. Corneal staining across the five zones of the cornea is shown in Figure 2. There was a significant positive correlation between blinking patterns with corneal staining in soft CL wearers (Spearman $\rho=0.378, p=$ $0.015)$. Between the two groups, partial blinker subjects presented with corneal staining.

\section{COMPLIANCE}

Only $10(24.4 \%)$ subjects obtained their contact lenses prescription via a thorough eye examination, while 31 (75.6\%) subjects purchased over-the-counter lenses. Thirty-four $(82.9 \%)$ subjects wore monthly disposable CL, while 7 (17.7\%) subjects preferred daily disposable lenses. Table 3 shows the response of the subjects towards CL compliance. Subjects were categorized as having a good compliance level towards lens care if they responded positively towards questions on good compliance. Overall, a total of $26(63.4 \%)$ subjects showed good compliance level toward CL care.

A multiple linear regression analysis was conducted to predict subjects' corneal staining based on blinking patterns and compliance level. The result of the regression indicated that the model explained $20.6 \%$ of the variance $\left(\mathrm{R}^{2}=0.206\right)$. Our results also showed that the model was a significant predictor of corneal staining $(\mathrm{F}(2,38)=4.941, \mathrm{p}=0.012)$. While blinking patterns contributed significantly to corneal staining $(B=0.140$, $\mathrm{p}=0.015)$, compliance level did not $(\mathrm{B}=-0.038, \mathrm{p}=$ $0.471)$. The regression equation was Corneal Staining $=$ $0.219+(0.140 *$ Blinking patterns $)+(-0.038 *$ Compliance level).

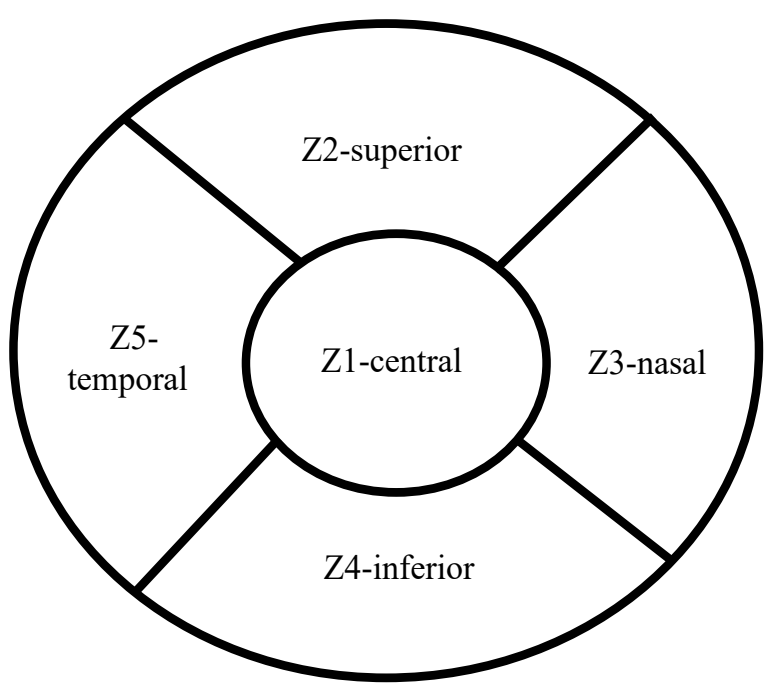

FIGURE 1. Five corneal zones for grading corneal staining 


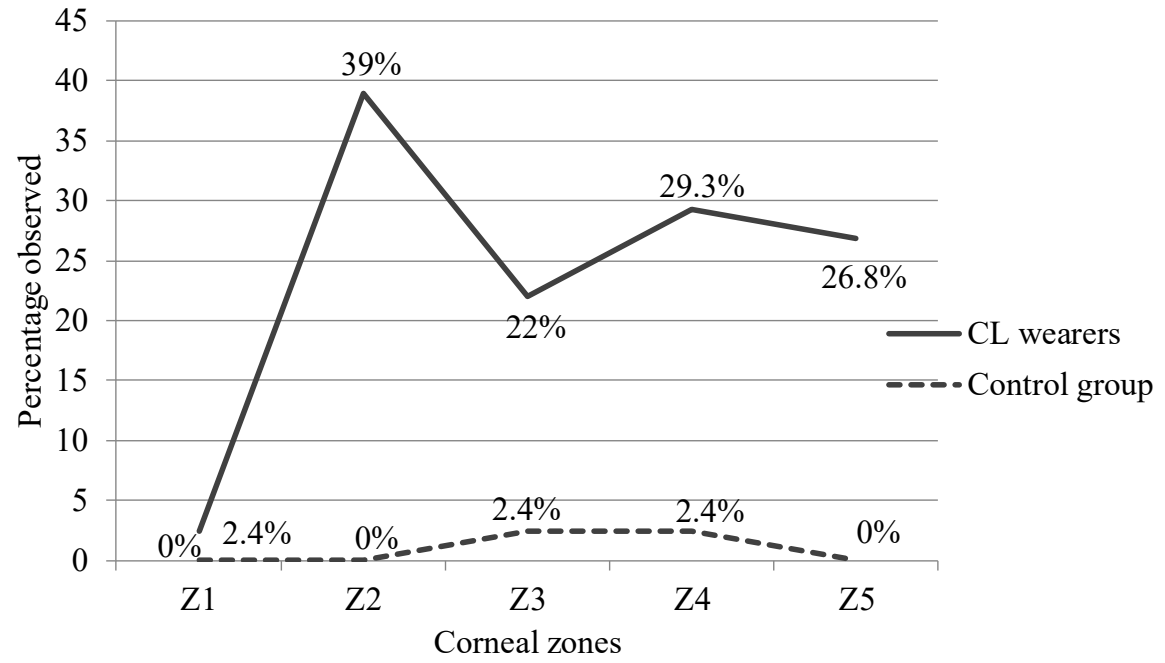

FIGURE 2. Corneal staining observed at different zones of the cornea between CL wearers and control group

TABLE 1. Demographic data of subjects

\begin{tabular}{lcccccc}
\hline \multirow{2}{*}{ Group } & \multicolumn{3}{c}{ Gender $(\mathrm{n})$} & \multicolumn{3}{c}{ Race $(\mathrm{n})$} \\
\cline { 2 - 6 } & Male & Female & Total & Malay & Chinese & Total \\
\hline CL wearer & 4 & 37 & 41 & 12 & 29 & 41 \\
Control & 9 & 32 & 41 & 21 & 20 & 41 \\
Total & 13 & 69 & 82 & 33 & 49 & 82 \\
\hline
\end{tabular}

TABLE 2. The mean grade of corneal staining of each zone in CL wearers and control group

\begin{tabular}{ccc}
\hline Cornea zone & CL wearers & Control group \\
\hline Z1 & $0.012 \pm 0.078$ & - \\
Z2 & $0.222 \pm 0.336$ & - \\
Z3 & $0.129 \pm 0.291$ & $0.012 \pm 0.078$ \\
Z4 & $0.217 \pm 0.371$ & $0.012 \pm 0.078$ \\
Z5 & $0.166 \pm 0.339$ & - \\
\hline
\end{tabular}

Z1-central, Z2-superior, Z3-nasal, Z4-inferior, Z5-temporal 
TABLE 3. Response of subjects towards CL compliance

\begin{tabular}{lccc}
\hline Questions & Yes & No & Sometimes \\
\hline Replace the expired disinfectant solution & 26 & 11 & 4 \\
& $(63.4 \%)$ & $(26.8 \%)$ & $(9.8 \%)$ \\
Add new CL solution with an existing solution & 2 & 37 & 2 \\
& $(4.9 \%)$ & $(90.2 \%)$ & $(4.9 \%)$ \\
Wash hand before handling CL & 40 & 0 & 1 \\
& $(97.6 \%)$ & $(0 \%)$ & $(2.4 \%)$ \\
Rinse CL with tap water & 0 & 40 & $(2.4 \%)$ \\
& $(0 \%)$ & $(97.6 \%)$ & 4 \\
Sleep with CL on & 0 & 37 & $(9.8 \%)$ \\
& $(0 \%)$ & $(90.2 \%)$ & 10 \\
Use expired CL & 2 & 29 & $(24.4 \%)$ \\
Follow CL care instruction & $(4.9 \%)$ & $(70.7 \%)$ & 12 \\
\hline
\end{tabular}

\section{DISCUSSION}

In this study, two types of eye blinking patterns (complete and incomplete) were recorded. Almost $71 \%$ of the soft CL wearers and $73 \%$ of the control subjects had complete blinking pattern. These results are in agreement with previous studies which reported that about 80 to $90 \%$ of the blinking was classified as complete, and 10 to $20 \%$ as incomplete (Abelson \& Holly 1977; Carney \& Hill 1984; Collins et al. 1989; Ishak et al. 2011). Incomplete eye blinking is believed to occur exclusively, or in conjunction with complete eye blinking (Himebaugh et al. 2009). It is also interesting to note that rigid gas permeable contact lenses have a larger influence on the number of complete and incomplete blinking patterns, compared to other types of lenses (Van Der Worp et al. 2008).

The grading of corneal staining is important in a routine eye examination to detect any abnormalities of the cornea layers of CL patients. The results in this study showed that there was some degree of corneal staining in normal non-CL wearers. A previous study highlighted that $79 \%$ of the normal population stained positively with fluorescein (Dundas et al. 2001). Contradictory to the findings by Dundas et al. (2001), this study only reported that only $4.9 \%$ of normal non-CL wearers had corneal staining. The stark difference seen between the two studies may be due to the younger cohort in this study, as opposed to the age of the subjects in Dundas' group, where they were in their 50s.

Almost $63 \%$ of the soft CL wearers presented with some degree of corneal staining, and $14.6 \%$ of them had worse than grade 1 of corneal staining. The average overall corneal staining among soft CL wearers was $0.38 \pm 0.39$ unit. According to Begley et al. (1996), 30\% of hydrogel CL wearers had significant corneal staining worse than grade 1 and the average overall corneal staining was 0.50 \pm 0.53 unit. The results of our study were supported by previous studies which reported that more than $50 \%$ of soft hydrogel contact lens wearers showed some degree of corneal staining (Nichols \& Sinnott 2011; Nichols et al. 2002). However, we showed a much higher percentage of corneal staining in our study compared to the studies done by Nichols and Sinnott (2011) and Nichols et al. (2002) and a much lower average corneal staining compared to the studies done by Begley et al. (1996). Classification of corneal staining, sample size, methods and grading scales might contribute to these differences.

Corneal staining was found more at the corneal periphery, especially in the superior $(39 \%)$ and inferior (29.3\%) regions. The same findings were also reported by Jalbert et al. (1999) and Mohidin and Zulkipli (2019). Begley et al. (1996) suggested that corneal staining found on the superior region was due to the deficiency of tears on the superior cornea caused by the pressure of upper eyelid on the cornea. Corneal staining in the inferior region may be due to the unstable tear film layer at the edge of the tear lid meniscus (Guillon et al. 1990).

Corneal staining among contact lens wearers may be caused by several factors. In this study, $90.9 \%$ of partial blinkers had corneal staining. Partial blinking is known to cause insufficient lens movement and contribute to poor 
tear circulation, that will likely increase corneal staining. Indeed, contact lens replacement schedule significantly affects corneal staining (Nichols et al. 2002). More corneal staining was found among conventional lens wearers compared to daily disposable lens wearers. More corneal staining, but not moderate or severe staining, was also found among contact lens wearers who frequently used. However, this correlation may not be causal. Corneal staining may be caused by dry eyes, and dry eye patients tend to use rewetting drops more frequently (Begley et al. 1996). Inappropriate fitting of contact lens may cause moderate to severe corneal staining (worse than grade 3 ). Hyperope and high myope contact lens wearers were more prone to present this severity of corneal staining.

A larger number of subjects $(90.2 \%)$ knew that soft contact lens cleaning solution only lasts for 90 days after the solution was opened. But only $63.4 \%$ subjects reported that they replaced their expired disinfectant solution with a new one. Most of the subjects were satisfied with their multipurpose solution. Only $12.2 \%$ subjects changed their contact lens care solution. The reasons they changed the type of lens care solution were to test the suitability of the solution, and to reduce the cost of lens maintenance. A previous study listed several factors that reduced contact lens subjects' compliance, including complexity, duration and cost of contact lens care (Davidson \& Akingbehin 1980).

In this study, only one subject occasionally cleaned her hands before handling contact lenses, while the remaining $97.6 \%$ subjects always cleaned their hands before handling contact lenses. Previous studies reported that 90 to $98 \%$ of the subjects cleaned their hands before handling contact lenses (Bhandari \& Hung 2012; Tajunisah et al. 2008). Hand hygiene is the most important part of contact lens care as it can reduce the risk of eye infections (Stapleton et al. 2008).

All subjects knew that contact lenses should be removed before sleep but only $90.2 \%$ subjects reported that they did not wear contact lenses while sleeping, while the remaining $9.8 \%$ (four) subjects wore contact lenses occasionally while sleeping. However, out of the four subjects, two of them wore silicone hydrogel contact lens. So, it was concluded that only two subjects did not comply with proper removal of contact lenses. According to a different study conducted by Tajunisah et al. (2008), $13.2 \%$ of their subjects consisting of 121 medical students from University of Malaya admitted that they sometimes did not remove their contact lenses while sleeping. Hence, the compliance with contact lenses removal was higher in our study compared to the one done in the past.

Only $29.3 \%$ subjects complied with contact lens wearing time guidelines, while the remaining did not comply. Out of the $29(70.7 \%)$ subjects, 22 of them wore hydrogel contact lens. Exceeding the recommended wearing time was not recommended for hydrogel contact lens wearers as it may cause eye complications due to a lack of oxygen supply.

This study showed that only $4.9 \%$ of the subjects underwent aftercare examination. A previous study reported that a total of $24 \%$ of contact lens wearers often forgot their follow up appointments, while $29 \%$ of contact lens wearers did not know how frequently aftercare examination should be done (Bhandari \& Hung 2012). Aftercare examination is necessary because it allows for early detection of physiological changes in the eyes. Poor and inadequate contact lens care caused by lack of awareness may increase the risk of contact lens complications.

In the past, over $50 \%$ of contact lens wearers had violated the lens care instructions, sometimes to the extent that it can be described as an abuse of the product (Bowden et al. 1989; Claydon \& Efron 1994; Efron \& Fitzgerald 1996). However, in this study, it was found that more than $70 \%$ of soft contact lens wearers followed contact lens care instructions. This result indicates that the subjects were well informed about the importance of following the given instructions.

Previous studies have reported on blinking patterns and corneal staining (Collins et al. 2006; Ishak et al. 2012), and corneal staining and compliance level (Collins \& Carney 1986; Nichols et al. 2002). To the best of our knowledge, no study has studied the association between blinking patterns, corneal staining and compliance level. From our study, blinking patterns contributed significantly towards corneal staining, while compliance level did not. However, we do acknowledge the limitation of the study was using a questionnaire to measure compliance level, which may present some bias. Although questionnaires are one of the most affordable and practical ways to gather quantitative data, subjects or respondents may not always be truthful with their answers.

\section{CONCLUSION}

There was no difference in eye blinking patterns between the soft CL wearers and the control group. This study also showed that corneal staining was significantly different between soft CL and non-CL wearers, and that corneal staining was influenced by blinking patterns. The overall results showed that $63.4 \%$ of the subjects had good compliance towards lens care.

\section{ACKNOWLEDGEMENTS}

The authors would like to thank campus Kuala Lumpur students for participating in this study. 


\section{REFERENCES}

Abelson, M.B. \& Holly, F.J. 1977. A tentative mechanism for inferior punctuate keratopathy. American Journal of Ophthalmology 83(6): 866-869.

Begley, C.G., Barr, J.T., Edrington, T.B., Long, W.D., McKenney, C.D. \& Chalmers, R.L. 1996. Characteristics of corneal staining in hydrogel contact lens wearers. Optometry and Vision Science 73(3): 193-200.

Bergmanson, J. 2006. Interpretation of corneal staining on your patient and in the literature. Nordic Vison 6: 8-9.

Bhandari, M. \& Hung, P.R. 2012. Habits of contact lens wearers toward lens care in Malaysia. The Medical Journal of Malaysia 67(3): 274-277.

Bowden, F.W., Cohen, E.J. \& Arentsen, J.J. 1989. Patterns of lens care practices and lens product contamination in contact lens associated microbial keratitis. Contact Lens Association of Ophthalmologists 15(1): 49-54.

Bui, T.H., Cavanagh, H.D. \& Robertson, D.M. 2010. Patient compliance during contact lens wear: Perception, awareness and behavior. Eye Contact Lens 36(6): 334-339.

Carney, R.G. \& Hill, R.M. 1984. Variation in blinking behavior during soft lens wear. International Contact Lens Clinic 11(4): 250-253.

Claydon, B.E. \& Efron, N. 1994. Non-compliance in contact lens wear. Ophthalmic and Physiological Optics 14(4): 356-364.

Collins, M.J. \& Carney, L.G. 1986. Compliance with care and maintenance procedures amongst contact lens wearers. Clin. and Experimental Optometry 69(5): 174-177.

Collins, M.J., Iskander, D.R., Saunders, A., Hook, S., Anthony, E. \& Gillon, R. 2006. Blinking patterns and corneal staining. Eye Contact Lens 32(6): 287-293.

Collins, M.J., Seeto, R., Campbell, L. \& Ross, M. 1989. Blinking and corneal sensitivity. Acta Ophthalmology 67(5): 525-531.

Davidson, S.I. \& Akingbehin, T. 1980. Compliance in ophthalmology. Transactions of the Ophthalmological Societies of the United Kingdom 100(Pt2): 286-290.

Dundas, M., Walker, A. \& Woods, R. 2001. Clinical grading of corneal staining of non-contact lens wearers. Ophthalmic and Physiological Optics 21(1): 30-35.

Efron, N. \& Fitzgerald, J.P. 1996. Distribution of oxygen across the surface of the human cornea during soft contact lens wear. Optometry and Vision Science 73(10): 659-665.

Guillon, J.P., Guillon, M. \& Malgouyres, S. 1990. Corneal desiccation staining with hydrogel lenses: Tear film and contact lens factors. Ophthalmology and Physiological Optics 10(4): 343-350.

Hamano, H., Kitano, J., Mitsunaga, S., Kojima, S. \& Kissling, G.E. 1985. Adverse effects of contact lens wear in a large Japanese population. Contact Lens Association of Ophthalmologists 11(2): 141-147.

Hart, W.M. 1992. Adler's Physiology of the Eye: The Eyelids. St. Louis: Mosby.

Himebaugh, N.L., Begley, C.G., Bradley, A. \& Wilkinson, J.A. 2009. Blinking and tear break-up during four visual tasks. Optometry and Vision Science 86(2): E106-E114.

Ishak, B., Thye, J.J.Y., Mohd-Ali, B. \& Mohidin, N. 2012. Blinking characteristics and corneal staining in different soft lens materials. World Academy of Science, Engineering and Technology 72: 1661-1665.

Jalbert, I., Sweeney, D.F. \& Holden, B.A. 1999. The characteristics of corneal staining in successful daily and extended disposable contact lens wearers. Clinical Experimental Optometry 82(1): 4-10.

Kikkawa, D.O., Lucarelli, M.J., Shovlin, J.P., Briggs, E., Cook, J. \& Lemke, B.N. 2003. Adler's Physiology of the Eye: Opthalmic Facial Anatomy and Physiology. St Louis: Mosby.

Kwon, K.A., Shipley, R.J., Edirisingre, M., Ezra, D.G., Rose, G., Best, S.M. \& Cameron, R.E. 2013. High-speed camera characterization of voluntary eye blinking kinematics. Journal of The Royal Society Interface 10(85): 20130227.

Mohidin, N. \& Zulkipli, N.N. 2019. Tears stability, corneal staining and dry eye symptoms in contact lens wearers. Jurnal Sains Kesihatan Malaysia 17(2): 35-41.

Nichols, J.J. \& Sinnott, L.T. 2011. Tear film, contact lens, and patient factors associated with corneal staining. Investigative of Ophthalmology Vision Science 52(2): 1127-1137.

Nichols, K.K., Mitchell, G.L., Simon, K.M., Chivers, D.A. \& Edrington, T.B. 2002. Corneal staining in hydrogel lens wearers. Optometry and Vision Science 52(2): 20-30.

Stapleton, F., Keay, L., Edwards, K., Naduvilath, T., Dart, J.K., Brian, G. \& Holden, B.A. 2008. The incidence of contact lens-related microbial keratitis in Australia. Ophthalmology 115(10): 1655-1662.

Tabery, H.M. 1997. Micropunctate fluorescein staining of the human corneal surface: Microerosions or cystic spaces? Acta Ophthalmology 75(2): 134-136.

Tajunisah, I., Reddy, S.C. \& Phuah, S.J. 2008. Knowledge and practice of contact lens wear and care among medical students of University of Malaya. The Medical Journal of Malaysia 63(3): 207-210

Teenan, D.W. \& Beck, L. 2001. Contact lens-associated chemical burn. Contact Lens Anterior Eye 24(4): 175-176.

Weisbarth, R.E. \& Henderson, B. 2005. Hydrogel lens care regimens and patient education. Clinical Contact Lens Practice 19: 381-419.

Van Der Worp, E., De Brabander, J., Swarbrick, H. \& Hendrikse, F. 2008. Eyeblink frequency and type in relation to 3- and 9-o'clock staining and gas permeable contact lens variables. Optometry and Vision Science 85(9): E857-E866.

Woods, J., Varikooty, J., Fonn, D. \& Jones, L.W. 2018. A novel scale for describing corneal staining. Clinical Ophthalmology 12: 2369-2375.

Bashirah Ishak*, Nur Sakinah Saad, Lim Siew Lee, Norlaila Mat Daud \& Bariah Mohd Ali

Optometry \& Vision Sciences Programme

Faculty of Health Sciences

Universiti Kebangsaan Malaysia

Jalan Raja Muda Abdul Aziz

50300 Kuala Lumpur, Wilayah Persekutuan

Malaysia

Norhani Mohidin

School of Optometry

Universiti Teknologi MARA

42300 Bandar Puncak Alam, Selangor Darul Ehsan

Malaysia

*Corresponding author; email: bashirah@ukm.edu.my

Received: 26 August 2019

Accepted: 17 May 2020 